\title{
POLICIES TO SUPPORT WIND POWER DEPLOYMENT KEY CONSIDERATIONS AND GOOD PRACTICES
}

Sadie Cox, Suzanne Tegen, lan Baring-Gould, Frank A. Oteri, and Sean Esterly

National Renewable Energy Laboratory

Trudy Forsyth

Wind Advisors Team

Ruth Baranowski

High Desert Technical Communications LLC 


\section{POLICIES TO SUPPORT WIND POWER DEPLOYMENT KEY CONSIDERATIONS AND GOOD PRACTICES}

Sadie Cox, Suzanne Tegen, lan Baring-Gould, Frank A. Oteri, and Sean Esterly National Renewable Energy Laboratory

Trudy Forsyth

Wind Advisors Team

Ruth Baranowski

High Desert Technical Communications LLC 


\section{NOTICE}

This manuscript has been authored by employees of the Alliance for Sustainable Energy, LLC ("Alliance") under Contract No. DE-AC36-08GO28308 with the U.S. Department of Energy ("DOE").

This report was prepared as an account of work sponsored by an agency of the United States government. Neither the United States government nor any agency thereof, nor any of their employees, makes any warranty, express or implied, or assumes any legal liability or responsibility for the accuracy, completeness, or usefulness of any information, apparatus, product, or process disclosed, or represents that its use would not infringe privately owned rights. Reference herein to any specific commercial product, process, or service by trade name, trademark, manufacturer, or otherwise does not necessarily constitute or imply its endorsement, recommendation, or favoring by the United States government or any agency thereof. The views and opinions of authors expressed herein do not necessarily state or reflect those of the United States government or any agency thereof. 


\section{Acknowledgments}

The authors would like to thank Ron Benioff, Terri Walters, Victoria Healey, Jaquelin Cochran, Jeffrey Logan, David Mooney, Jenny Heeter, and Jen Abbott of the National Renewable Energy Laboratory, Ian Lloyd of the U.S. Department of Energy, and Larry Flowers of G4Wind for their review and insights. All information and any omissions are the responsibility of the authors, not the reviewers. 


\section{Table of Contents}

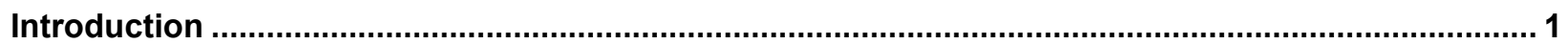

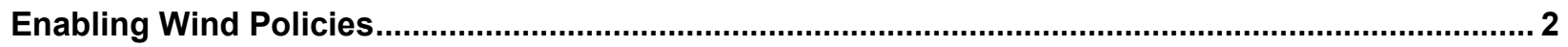

Renewable Electricity Standards ................................................................................ 2

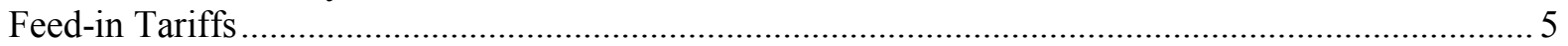

Interconnection Standards and Net Metering for Distributed Wind........................................... 7

Wind Investment and Production Tax Credits ....................................................................... 8

Further Approaches to Support Private Investment ............................................................. 11

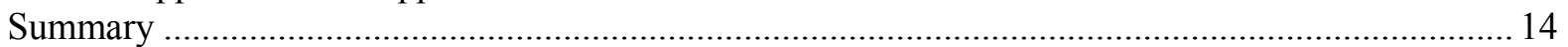

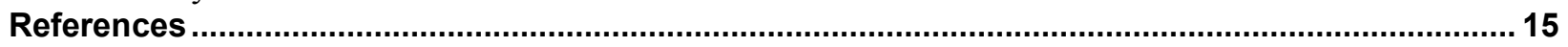

Appendix. Additional Support and Resources ........................................................................ 18 


\section{List of Tables}

Table 1. Summary of Good Practices and Considerations

\section{List of Text Boxes}

Text Box 1. Key RES design elements across renewable energy technologies........................................ 2

Text Box 2. Thailand: Setting ambitious renewable energy and wind targets......................................... 3

Text Box 3. Chile: Designing a robust renewable energy policy environment and integrating wind with

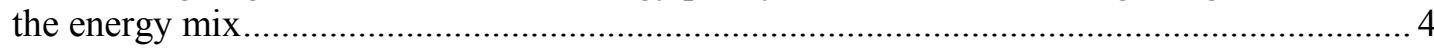

Text Box 4. Key FIT design elements across renewable energy technologies ........................................ 5

Text Box 5. United Kingdom: Ensuring technology standards to support successful FIT outcomes........... 6

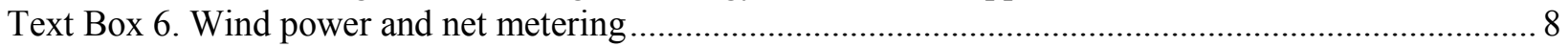

Text Box 7. Nicaragua: Supporting renewable energy deployment through tax incentives and a broader

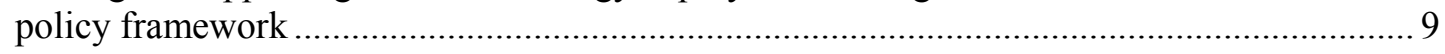

Text Box 8. India: Supporting wind power with tax incentives and ensuring project sustainability.......... 10

Text Box 9. Texas: Competitive renewable energy zones and transmission expansion to support scaled-up wind investment

Text Box 10. Germany and Denmark: Supporting wind power through streamlined permitting and CREZ 


\section{Introduction}

Wind power is playing a significant role in meeting global electricity demand while also supporting local economic development, mitigation of carbon emissions, and reduction of water use from the power sector. Global wind power capacity has expanded, on average, $21 \%$ annually since 2008, with at least 85 countries having implemented commercial wind operations by 2013 (REN21 2014). As notable examples, in 2014, wind power provided 28\% of electricity in Denmark (Danish Wind Energy Association 2015), 28.5\% in Iowa, United States (Iowa Wind Energy Association 2015), and $21 \%$ in Spain (RED Electrica de Espana 2014). In several countries, ${ }^{1}$ wind power is increasingly cost-competitive with fossil fuel generation, and in some cases, it has reached wholesale costs at or below conventional generation, which is referred to as grid parity (REN21 2014). ${ }^{2}$ A number of energy policies have played an important role in scaling up wind deployment and increasing its economic viability, while also supporting country-specific economic, social, and environmental development goals.

Policies to support wind energy are often designed to align with broader objectives including diversification of electric generation sources to increase long-term price stability; reduction of greenhouse gas emissions and water use; and technology innovation to increase global competitiveness. Objectives specific to national and subnational contexts can provide broader framing for tailored design and implementation of wind power policies described in this paper.

Although wind power has become cost-competitive in several contexts, challenges to wind power deployment still exist. Key barriers include:

- Lack of consistent policy signals, which can create uncertainty in markets

- Unstandardized and time-consuming regulatory and permitting processes

- Concerns of utilities related to integration of distributed or variable power on the grid

- Public concern related to visual, sound, land use, and other environmental impacts that may be associated with wind

- Need for post-installation and ongoing skilled labor for turbine maintenance in developing countries.

- At high wind penetration levels and in competitive wholesale markets, potential impacts on other generation sources due to low or negative bidding.

Within the context of country-specific goals and challenges, policymakers are seeking to learn from successful wind deployment approaches around the world. As part of the Clean Energy Solutions Center's Clean Energy Policy Brief Series that describes key policy design elements across renewable energy technologies, this paper presents approaches and considerations specific for small and utility-scale wind power deployment. ${ }^{3}$ Drawing from international experience and lessons, the

\footnotetext{
${ }^{1}$ Australia, Brazil, Chile, Mexico, New Zealand, South Africa, Turkey, much of the European Union, India, and parts of the United States (REN21 2014).

${ }^{2}$ In the United States, costs for new wind power (purchase agreements) at the best resource locations have come in below the conventional costs for electricity (Wiser and Bolinger 2014).

${ }^{3}$ The most common wind turbines globally are utility-scale and typically range in size from 1.5 to 3.6 megawatts. Gridconnected smaller turbines (1.5-500 kilowatts) are suitable for powering homes or businesses and are considered in the paper.
} 
paper focuses on wind-specific good practices for renewable electricity standards, feed-in tariffs, interconnection standards, net metering, financial incentives, and approaches to enable private finance. Ultimately, governments can design a suite of complementary policies that aligns most appropriately with unique national circumstances, challenges, opportunities, and goals.

\section{Enabling Wind Policies}

Based on specific needs and circumstances, individual governments can tailor policies described in this section to support wind power deployment. In many cases, a combination of policies will be most effective in addressing country-specific objectives and challenges. While the policies presented here have some common key design elements across renewable energy technologies, ${ }^{4}$ the sections below provide insights on good practices and considerations specific for the wind sector, and they can be used as a starting point for more detailed policy design and implementation processes.

\section{Renewable Electricity Standards}

A renewable electricity standard (RES) sets a requirement for a region, utility, or country to purchase a specific amount of electricity from renewable sources. A full overview of the policy and related best practices, which are summarized in Text Box 1, can be found at cleanenergysolutions.org/policybriefs/res. As of 2013, 25 national and 54 subnational governments had adopted RES or similar policies. Even in the absence of wind-specific targets, RESs have significantly supported wind development in several countries and jurisdictions, as wind power is often the least-cost renewable energy option (IRENA 2012; Wiser and Bolinger 2014). RESs continue to be an important policy instrument to support wind power deployment globally.

\section{Good Practices and Considerations}

The following good practices and considerations draw from experience with RES design to support wind deployment and build on broader RES key design elements across renewable energy technologies (see Text Box 1).

- Establishing long-term RES targets that increase over time to support sustained wind growth - Renewable electricity standards and targets for wind deployment have been key in

\footnotetext{
${ }^{4}$ For the full Clean Energy Solutions Center Policy Brief Series, see cleanenergysolutions.org/policy-briefs.
} 
establishing a long-term policy signal to support wind market growth, ${ }^{5}$ especially in relation to financial incentives (such as production tax credits), which often have shorter timeframes. Adoption of long-term RESs (often with time horizons of 10 years and beyond) sends a critical message to investors and developers regarding ongoing support for wind deployment (Wiser and Bolinger 2014). However, given the economic competitiveness of wind power as compared to other renewable energy technologies, in several cases, wind RESs have been achieved very rapidly (Wiser and Bolinger 2014). Thus, policymakers can consider increasing RES targets over time to align with changing market conditions and to support sustained growth of the industry, while also recognizing possible physical constraints or limits related to grid integration, especially in island and remote contexts. While RES increases may be planned during initial policy adoption, the strength and timing of these targets can be revisited as wind deployment increases, especially in cases where growth occurs rapidly (IRENA 2012). Text Box 2 highlights Thailand's renewable energy targets, which increase over time to support sustained deployment.

- Defining the standard to support wind generation-Renewable electricity standards have varying definitions related to the requirements to meet the standard, and they are often linked to total renewable energy generated (or sold) or installed power plant capacity. These definitions greatly impact policy outcomes. For example, an RES requiring $20 \%$ of installed power plant capacity to come from wind can have much different outcomes than an RES requiring $20 \%$ of total electricity generation (or sales) to be met with wind. The latter will result in greater support for wind. This is true because wind technologies depend on variable resources, and while their "rated" power plant capacity (in megawatts) may be the same as a conventional power plant, the overall power output (in kilowatt-hours) will be lower on an annual basis. Setting RES in relation to a capacity credit calculation ${ }^{6}$ or as a percentage of generation or consumption are two approaches to maximize wind deployment (IRENA 2012).

Text Box 2. Thailand: Setting ambitious renewable energy and wind targets

In 2008, the Thailand Ministry of Energy published the Renewable Energy Development Plan, 2008-2022 (REDP). The REDP set a target to meet $20 \%$ of final energy demand with renewable energy by 2020. Targets leading up to 2020 were also set, with $15.6 \%$ by 2011 and $19.1 \%$ by 2016 . In 2011, the plan was updated with more aggressive intermediate targets and became the Alternative Energy Development Program, 2012-2021 (AEDP). The AEDP set a total target of 5,608 megawatts (MW) of renewable electricity generation by 2021 , or $19.3 \%$ of installed capacity. The AEDP also sets technology specific targets for 2021 , including $800 \mathrm{MW}$ of wind, and $500 \mathrm{MW}$ of solar power, with the greatest share of renewable energy coming from biomass. Other policy instruments to support the targets include production mandates, tax incentives, R\&D support, and public awareness programs. Thailand also implemented a feed-in tariff known as the "Adder Program." The program allows participants to sell renewable electricity at a specific tariff level, depending on the technology, with the rates for wind and solar guaranteed for 10 years. Thailand's experience is an example of a multi-faceted policy package enabling wind and renewable energy development (Asian Development Bank 2013).

\footnotetext{
${ }^{5}$ In 2013, $93 \%$ of U.S. wind power capacity was in states with RESs (Wiser and Bolinger 2014).

${ }^{6}$ A capacity credit or capacity value is "the contribution of a power plant to reliably meet demand. Capacity value is measured in terms of either physical capacity ( $\mathrm{kW}, \mathrm{MW}$, or $\mathrm{GW})$ or the fraction of the power plant's nameplate capacity (\%). For example, a plant with a nameplate capacity of $150 \mathrm{MW}$ and a capacity value of $50 \%$ could reduce the need for conventional capacity by 75 MW." - USAID Greening the Grid fact sheet (2015).
} 
- Enacting subnational RESs to support diverse wind resources and development needsWhile national RESs send a high-level and important signal of support for renewable energy development, subnational RESs can be tailored to specific local circumstance. For example, if a country or jurisdiction prioritizes wind development in a specific area (e.g., to support grid balancing cost reductions), location-specific requirements or bonuses within the RES can be effective tools to support such priorities. Subnational RESs can also facilitate engagement of local stakeholders in evaluating crucial environmental and land use considerations related to wind development. Local and subnational needs and goals can also be integrated with national-level RES through specific geographic set-asides or location requirements (Wiser and Bolinger 2014).

- Establishing set-asides for offshore wind technologies-RES set-asides can be critical in supporting offshore wind investment. If a country is interested in prioritizing offshore wind development, policymakers can consider designing an RES that includes an offshore wind set-aside. The set-aside can provide direct support to a newer market segment (Wiser and Bolinger 2014).

- Supporting a broader enabling policy environment-While RESs have been instrumental in supporting wind power development in several contexts, they often exist within a broader set of complementary wind support policies. Other policies and actions that have been critical in supporting wind development include financial incentives such as feed-in tariffs, and production and investment tax credits (described below); utility resource planning and requirements; regulatory actions that consider transmission needs of policies; wind research and development (R\&D); and voluntary green power markets (Wiser and Bolinger 2014). Considering RESs and wind targets within the context of the broader policy environment and developing complementary policy packages can support sustained wind market growth (IRENA 2012). Text Box 3 presents the Government of Chile's approach to support a broader policy environment for renewable energy as well as specific measures to facilitate wind deployment in rural areas.

Text Box 3. Chile: Designing a robust renewable energy policy environment and integrating wind with the energy mix

The government of Chile is supporting nonconventional renewable energy by harnessing significant resource potential. In 2008 , the government added to the existing general energy law by creating a renewable portfolio standard requiring $5 \%$ of electricity to come from non-conventional renewable energy sources by 2014 , gradually increasing the requirement to $10 \%$ by 2024 . Chile also created several energy-specific ministries within the government to help manage and develop the clean energy sector. Despite these efforts and a wind resource potential of 40 gigawatts, the amount of wind energy deployed in Chile is only $1 \%$ of the country's total energy capacity (ITAMS 2013).

Significant wind resources in Chile are located largely in the remote Patagonia region. Thus, wind resources are most easily harnessed for remote applications, rather than to power urban centers (ITAMS 2013). To support increased wind deployment at the rural level, the Clean Energy Solutions Center partnered with the Renewable Energy Center of Chile (RECC) on efforts to assess wind-diesel hybrid systems for energy access efforts in remote Chilean communities. Based on this partnership, RECC is supporting various rural wind energy efforts. 


\section{Feed-in Tariffs}

Feed-in Tariffs (FITs) provide a per kilowatthour payment for renewable electricity that is "fed" into the grid. FITs are designed to increase deployment of renewable energy technologies by offering a long-term purchase agreement for electricity generation at a specified price, thereby providing market certainty for developers (Couture et al. 2010; Klein et al. 2010). The Solutions Center's FIT policy brief ${ }^{7}$ provides a full overview of the policy and related best practices, which are summarized in Text Box 4.

As of 2013, 51 countries had adopted wind FITs ${ }^{8}$ making them one of the most widely used policies to support wind investment (REN21, n.d.). ${ }^{9}$

\section{Good Practices and Considerations}

Good practices and considerations for wind FIT design and implementation that are based on experience and lessons emerging from FIT development worldwide are highlighted below.
Text Box 4. Key FIT design elements across renewable energy technologies

- Setting and revising FIT payment levels in relation to technology, resource quality, project size, and location and adjusting policies in a predictable manner

- Considering a cost containment approach to avoid boom-and-bust scenarios

- Establishing long-term contracts and guaranteeing grid access to lower investor risk and cost of financing. Siting incentives and grid connection cost sharing can also support positive outcomes related to guaranteeing grid access

- Considering forecasting requirements to support grid operators in balancing renewable energy generation with system demand

- Streamlining administration and approvals to avoid barriers and reduce time and costs associated with project development.

For a full description of key FIT design elements, see cleanenergysolutions.org/policy-briefs/fit.

- Differentiating wind FIT payments in relation to resource quality-Electricity generation costs vary in relation to resource quality, thus FIT payment levels can be differentiated to support wind development under various resource conditions. This allows the payment to be appropriately aligned with generation costs at specific sites. One approach to set the FIT payment level in relation to resource quality is the "reference turbine approach," which bases payments on comparison of a reference yield with turbine generation over a five-year period. Various other approaches, such as "annual percentage yield" have been used by countries to set FIT payments in relation to resource quality. Differentiating FIT payments by resource quality supports economically viable development of diverse wind sites and avoids inflated payments to developers in wind resource rich areas. Designing tariffs in relation to resource quality also improves project siting flexibility and supports reductions in grid balancing costs through geographically dispersing wind development, thus avoiding bottlenecks and improving overall reliability (Couture et al. 2010; Klein et al. 2010).

For more information, see cleanenergysolutions.org/policy-briefs/fit.

${ }^{8}$ For a current list of countries, see the REN21 Renewables Interactive Map (map.ren21.net).

${ }^{9}$ FITs are most commonly used in Europe and Asia. 
- Differentiating wind FIT payments in relation to project size-Various countries have differentiated tariffs for smaller-scale wind (e.g., under 20 kilowatts). Differentiating tariffs by project size can support distributed projects, allow for improved tracking of generation costs by project size, and help avoid inflated developer payments for large projects (Couture et al. 2010; Klein et al. 2010). While smaller-scale wind projects may have higher costs, energy security and grid reliability benefits can support justification of costs. Text Box 5 describes the United Kingdom's approach to differentiating tariffs by project size while also supporting quality standards.

- Differentiating wind FIT payments for offshore wind development-To support offshore wind development, policymakers can offer higher tariffs in relation to location. Location-specific tariffs can be set broadly for offshore projects or in relation to distance from the shore, depth of water at the project location, or both. Varying tariffs by location can help support development of less accessible wind resources. Transmission cost savings for offshore wind can be achieved through siting projects near population centers (Klein et al. 2010).

- Differentiating wind FIT payments in relation to technology-Generally and to support a broader portfolio of technology options, policymakers often set wind tariff rates lower than tariffs for solar and other technologies that may have higher costs (Klein et al. 2010).

- Considering bonus payments and premiums to support broader wind development goalsThere are several cases for which policymakers might consider bonus payments and premiums in addition to feed-in tariffs to encourage certain types of wind development. In particular, policymakers can design bonus payments for developers that refurbish or "repower" older wind plants, or developers that implement innovative or nascent technologies such as offshore wind and advanced onshore wind technologies that support grid integration. In the latter case, these bonuses may support broader innovation and early technology adoption goals for the policy overall (Couture et al. 2010).

- Considering wind FIT price degression-Policymakers can also consider a tariff degression approach, or a decrease in the tariff over time, for wind FITs. Effectively designed FIT tariff degressions occur predictably and transparently to align with technology price decreases as the market develops, to increase investor confidence, and to support stable market growth (Rickerson et al. 2012). Pre-scheduling degressions rather than making unpredictable changes to tariffs is more supportive of a stable policy environment and can occur annually or on a fixed schedule most appropriate for the local market. Effective price degressions are often informed by robust market data and projections related to wind technology and economics. Particularly for wind, both onshore and offshore, carefully considering price degressions is 
important as cost fluctuations have occurred over the last few decades. In cases where wind prices may increase, price degressions can greatly hinder market growth ${ }^{10}$ (Wiser and Bolinger 2014; Klein et al. 2010; Couture et al. 2010; IRENA 2012).

- Considering caps on projects or capacity-Policymakers may choose to place caps on wind FIT project participation or capacity to avoid high costs and "boom and bust" scenarios. In some cases, when caps are designed on a "first-come, first-served" basis this can create a rush to interconnect before transmission is sufficiently upgraded, leading to curtailments. To avoid such issues, caps can be designed to allow developers to reserve slots, while also placing time limits on reserved slots. To quality for reserved slots, policymakers can also design clear project requirements in relation to grid infrastructure and project viability. Robust analysis of existing grid infrastructure as it relates to bringing new wind resources online can also inform effective design of FIT project caps.

\section{Interconnection Standards and Net Metering for Distributed Wind}

Distributed wind energy systems provide clean, renewable power while helping relieve pressure on the power grid and contributing to energy security for homes, farms, schools, factories, private and public facilities, distribution utilities, and remote locations (Forsyth and Baring-Gould 2007). The use of individual, smaller-scale turbines is increasing worldwide f or uses such as water pumping, rural electrification, battery charging, telecommunications, and national security (Gsanger 2013). ${ }^{11}$ Grid-connected distributed wind turbines are often most attractive in areas with high electricity costs, significant wind resources, flexible permitting and zoning, and ease of interconnection to the utility grid. Further, incentives and policies that provide economic benefit over a certain period and/or lower capital costs can also support distributed generation (WWEA 2014). ${ }^{12}$ Net metering (see Text Box 5) is one of the most commonly used distributed generation policies, with policies adopted in 44 countries by the end of 2013 (REN21 2014). Considerations and good practices for distributed generation policy are highlighted below.

\section{Good Practices and Considerations}

Good practices and considerations for distributed wind generation that are based on experience and lessons learned by small and distributed wind development globally are highlighted below.

- Establishing interconnection standards-Interconnection standards are a prerequisite for distributed wind generation projects. Interconnection standards detail the conditions under which distributed renewable energy generation is allowed to connect to the utility grid, and they are intended to provide clear guidelines to ensure grid reliability while reducing costs and delays for distributed generation projects. Interconnection policies ensure all renewable electricity projects can connect to the grid if they meet certain technical requirements to ensure safety. Interconnection policies often standardize connection procedures and technical requirements to avoid case-by-case utility decisions. Effective interconnection policies also provide simplified procedures and forms for small systems so as not to place a proportionately high administrative burden on small wind system installers and owners.

\footnotetext{
${ }^{10}$ From 2005-2008, offshore wind projects costs increased significantly; up to $60 \%$. Similarly for U.S. onshore wind, average real price increased by greater than 40\% from 2004 to 2007 (Couture et al 2010).

${ }^{11}$ While off-grid and mini-grid turbines are the most common wind technologies in developing countries, this paper focuses on grid-connected wind power. For more information on off-grid applications, see WWEA (2013).

${ }^{12}$ Policymakers can access the Distributed Wind Policy Comparison Tool (www.eformativeoptions.com/dwpolicytool/). Funded by the U.S. DOE, the tool uses a dashboard-interfaced pro forma financial model to calculate the impact of rebates, tax credits, FITS, and other incentives and policies on distributed wind project economics.
} 
If grid capacity to incorporate variable renewable energy resources such as wind or solar is an issue - for example with remote or island gridsinterconnection policies can specify caps or trigger studies by authorities as certain levels are reached. However, avoiding requirements for utility studies or other large costs for small projects can support more efficient policy outcomes.

- Considering a wind net metering policy-Welldesigned net metering policies can support effective distributed wind electricity markets. Coupled with robust interconnection standards, net metering can ensure that utility customers who lease or own small-scale distributed wind technologies receive value for energy they produce and feed back to the grid. Because net metering policies are typically

Text Box 6. Wind power and net metering

Typically, under a net metering policy, small wind turbines supply energy directly to a home or small business and any excess wind energy is provided to the supplying utility. The utility provides the customer with a credit for excess power that can be used against power used at other times. If, over some defined period, the customer has produced more power than they have used, the excess is paid to the customer at a pre-specified rate. Net metering allows customers to use an on-site wind turbine to offset their power use, even if power use occurs when the wind is not blowing. This often significantly impacts the economics of small wind projects. Many locations experience strong seasonal wind variations; therefore, a distributed wind turbine may produce more energy than the consumer demands in some months and much less in others. Banking excess generation on a yearly basis allows customers to accumulate electricity credits during high wind seasons and use them in months when less wind is available. Annual net metering, therefore, enhances the value of wind energy and reduces the cost and complexity of evaluating a site by eliminating questions regarding seasonal matching of load and wind. If net metering is not available, variability of the wind resource reduces the amount of wind-generated electricity that can be used because any excess cannot be banked and must be granted or sold to the utility at "avoided cost." Net metering is significantly impacting the economics of residential systems and is an important driver of small wind industry growth (Polaris 2015). designed to accommodate customers that want to offset their own power use, system size is often limited relative to customer load. Some policies allow customers to also produce power just for sale to the utility, but policymakers need to decide whether net metering or FIT policies work better in this instance. Annualized net metering, accounting for the power use versus power generated, often maximizes small wind turbine benefits to the customer, and it can stimulate the market in areas with high retail rates, offsetting high-cost electric services. However, policymakers must work closely with consumers, wind industry, utilities, and other stakeholders to design net metering policies that are most appropriate for local circumstances (IREC 2014). Text Box 6 provides a broad overview of net metering as a policy instrument to support distributed wind deployment.

\section{Wind Investment and Production Tax Credits}

Several countries have adopted tax incentives to support wind industry investments (IEA 2014). Two of the most widely adopted renewable energy tax incentives - investment and production tax credits - have been enacted in 37 countries (REN21, n.d.). A wind production tax credit (PTC) provides a credit to companies producing wind energy on a per-kilowatt-hour basis, while an investment tax credit (ITC) reduces the wind project owner's tax liability based on the capital investment in the project (Mendelsohn and Kreycik 2012). 


\section{Good Practices and Considerations}

When designing wind investment and production tax credits, policymakers can consider the good practices and considerations that are highlighted below, which are based on international experience.

- Establishing an appropriate incentive rate and controlling costs - To support equitable and efficient outcomes, wind tax incentives are normally tied to the incremental costs associated with wind power production. Generally, higher tax credit rates may be more likely to drive wind deployment, but will result, of course, in some loss of government tax revenue and can lead to less-experienced wind developers entering the market. Another issue for consideration is the cost of tax credit monetization, which can lead to high expenses for certain companies. Establishing an appropriate tax incentive rate, which depends greatly on various country circumstances, is not considered at length in this report. To control costs, policymakers may consider establishing a maximum incentive, either by individual

Text Box 7. Nicaragua: Supporting renewable energy deployment through tax incentives and a broader policy framework

To support an ambitious goal of providing $94 \%$ of electricity from renewable sources, including hydropower, geothermal, wind, and solar by 2017, Nicaragua is facilitating investment in renewable energy. As a notable example, the government implemented tax incentives for renewable energy that encouraged increased private investment in renewable energy projects (Otis 2015).

Building on these successful tax incentivesand to support a robust policy environmentthe Clean Energy Solutions Center partnered with the Nicaragua Ministry of Energy and Mines to identify additional policy actions to support renewable energy deployment. Collaboration included a gap analysis of the current wind, solar and biogas policies, evaluation of major market barriers, and identification of policies and regulations that could be adopted to address these barriers. Ultimately, the partnership sought to complement Nicaragua's tax incentives by supporting development of a strong policy framework that aligns with the country's ambitious renewable energy goals. project or for the entire program, to cap the credits provided. However, careful design of caps is extremely critical to avoid "boom-and-bust" scenarios (Wiser and Bolinger 2014; IRENA 2012; American Wind Energy Association 2014a).

- Supporting a stable policy environment-As described below, short timeframes or unpredictable changes to PTCs and ITCs can present significant challenges for wind industry investors and developers. To mitigate these issues, PTCs and ITCs can be coupled with a higher level renewable energy targets and RESs, described above, which can send a longerterm signal of support for wind deployment. As an example and as presented in Text Box 7, the Clean Energy Solutions Center partnered with the Government of Nicaragua to evaluate policy options that could complement and provide higher level framing for the country's renewable energy tax incentives. Policymakers can also consider longer re-approval timescales for PTCs and ITCs to support a more stable policy environment (Wiser and Bolinger 2014; IRENA 2012; American Wind Energy Association 2014a).

- Determining the tax incentive period - Policymakers can establish an appropriate tax incentive period to ensure policy objectives are achieved. For instance, in cases where deployment of utility-scale wind projects is a priority, project development may occur over multiple years. Thus, the timeframe can be set to incentivize longer-term project developers to participate. Conversely, if policymakers seek to drive rapid deployment, a very long timeframe could reduce incentive for near-term project development. Policymakers can also allow developers to receive tax credits at a certain stage of construction rather than at project 
completion to incentivize development that may occur beyond the term of the program. However, this could increase risks associated with project performance. To address this issue, policymakers can include a requirement that project developers maintain ownership for a specified number of years or forfeit a portion of the tax credit (Wiser and Bolinger 2014; IRENA 2012; American Wind Energy Association 2014a). Text Box 8 presents one of India's tax incentive approaches to support ongoing operation of wind projects.

Text Box 8. India: Supporting wind power with tax incentives and ensuring project sustainability

India's domestic income tax law provides a 10year tax holiday for wind generation and distribution projects, if power generation began before 31 March 2014. Under this policy, wind operations pay a minimum alternative tax of approximately $20 \%$ (based on income). After 10 years of operation, the tax can be offset. This policy design element helps to ensure ongoing operation of the plant and sustainable deployment outcomes (Boekhoudt and Behrendt 2014).

- Wind production tax credit considerations - Wind PTCs are typically implemented at the national level for a defined commercial operation timeframe, and they allow project developers to reduce the selling price of electricity from wind projects, thus reducing costs for power purchasers and consumers (Lantz et al. 2014). PTCs are effective at reducing government risks associated with project development, as they are based on production of energy, which inherently requires project operation. ITCs, on the other hand, do not explicitly incentivize actual production. Further, as a tax credit, a PTC does not require a direct expenditure of funds but rather allows companies to reduce their tax burden. Policymakers can consider an annual PTC value increase to spur wind development; however, ensuring predictable revisions is critical to avoid inconsistent market signals. Some PTCs have experienced challenges associated with political transitions and frequent policy changes. Under these circumstances, "stop-and-start" signals can lead to a climate of uncertainty for wind energy developers, buyers, and the workforce (Wiser and Bolinger 2014; IRENA 2012; American Wind Energy Association 2014a).

- Wind investment tax credit considerations - ITCs can be very impactful for capital-intensive technologies such as wind, as the incentive is based on total project cost rather the cost of electricity generation, and thus, the incentive can often be realized in the early stages of project development. Given possible early realization of incentives, policymakers can consider methods to reduce risks and ensure that the project operates over its full, expected life. One option is for policymakers to include a requirement that project developers maintain ownership for a specified number of years or forfeit a portion of the tax credit. ITCs also face risks associated with political transitions and policy adjustments, and they can be coupled with robust higher-level renewable energy support frameworks to mitigate this challenge (Wiser and Bolinger 2014, IRENA 2012, American Wind Energy Association 2014b).

- Supporting non-taxable entities-Policymakers can also consider incentive options for nontaxable entities, such as schools, governments, or municipal utilities to use either ITCs or PTCs. Two options are allowing partnerships with tax equity providers and/or establishing a parallel program. For example, the U.S. Treasury established a Clean Renewable Energy Bond program to provide low-cost financing for tax-exempt municipal governments (Bipartisan Policy Center 2011). 


\section{Further Approaches to Support Private Investment}

In addition to the policies described above, policymakers can consider several further actions to catalyze private wind investment. Four notable actions include identifying areas with significant wind resources and transmission infrastructure for wind connections; reducing the risk and cost of capital for wind projects; designing wind ordinances; and streamlining wind-permitting processes. While several other actions can be taken to support private investment, including the policies described in the sections above, these four key areas can be critical in setting the stage for scaled-up private investment.

- Identifying Competitive Renewable Energy Zones-To support wind investment, policymakers can consider identification of Wind Energy Areas or competitive renewable energy zones (CREZ). Under this approach, governments, in cooperation with various stakeholders, identify areas with significant wind resources and conduct initial evaluations to support wind development, with a major focus on transmission planning. Under a comprehensive CREZ process, a government and/or utility defines the CREZ area, conducts resource, geotechnical and environmental assessments, secures land rights, works with local communities to complete general permitting requirements, installs transmission (in some cases), and releases a request for wind development proposals and/or offers power purchase agreements to potential developers. Early and ongoing engagement and cooperation with stakeholders such as local authorities, regulatory agencies, utilities and electrical grid operators, landowners, developers and communities can support identification of optimal locations for wind generation, minimize issues associated with development, and support identification of local economic development opportunities. Ultimately,

Text Box 9. Texas: Competitive renewable energy zones and transmission expansion to support scaled-up wind investment

In 2008, the U.S. state of Texas designed a CREZ in response to a public mandate to increase renewable energy generation to meet electricity demand and address a shortage of transmission capacity from wind-rich areas to load centers of the state (Public Utility Commission of Texas 2014). Ultimately, as one of the most significant transmission efforts ever devoted to wind power, the CREZ resulted in a 3,588-mile transmission development project being completed in 2013 with the potential to bring nearly $18,500 \mathrm{MW}$ of wind energy to the highest energy demand areas of the state (Wiser and Bolinger 2014).

One key element of Texas's CREZ success was that it allowed transmission to be developed (and costs to be recovered) before generation began. Because transmission installation takes longer than power plant installation, this allowed the development timescales to be better-aligned (Cochran et al. 2012).

As an outcome of the CREZ process and transmission expansion, Texas wind energy development has increased rapidly. At the end of 2014, Texas had a total wind capacity of 12.4 GW (REN21 2014) with 4600 MW of planned capacity additions in 2015 and 2016. (Wiser and Bolinger 2014). As demonstrated by this success, establishing and supporting CREZ can be a highly effective approach to support scaledup wind investment.

developing a CREZ can be an effective approach to enable private investment through reducing project risks, costs, and upfront planning time; streamlining permitting and interconnection processes; and in some cases, supporting transmission infrastructure expansion and/or upgrades (Cochran et al. 2012, EU 2013.) Text Box 9 presents key design elements of Texas's CREZ. 
- Reducing risk and cost of capital-As large-scale wind projects are capital-intensive (UNDP 2012), low-interest or guaranteed/partially guaranteed loans can be critical in supporting private wind investment, especially in developing countries. While low interest loans more directly focus on reducing the cost of capital for projects, guaranteed or partially guaranteed loans reduce the risk to private banks, and in turn, lower the cost of capital and allow the project to access wider capital markets. Multilateral development banks, such as the World Bank and its subsidiary the International Finance Corporation ${ }^{13}$ as well as national development banks can be critical partners in supporting low interest and guaranteed loan provision, especially those that factor in sustainability of investments. Critical safeguards related to low interest and loan guarantee programs include development of a transparent review and vetting process, due-diligence on the part of the loan originator, and long-term project oversight. Loan programs can also require that the technology for investment meet some level of international technical standards (Stadelmann et al. 2014).

- Designing wind ordinances - National, regional, and local regulations govern many aspects of wind energy development. Subnational governments and rural governing bodies often enact wind energy ordinances to regulate aspects of wind projects such as their location, permitting process, and construction to ensure safe, effective, and efficient installations of distributed wind energy systems. Where wind has not been considered directly, zoning or permitting processes set in place for buildings can have unintended consequences on small wind development. Local policymakers can use model zoning ordinances developed by organizations such as the Distributed Wind Energy Association, and they can review current ordinances in place to inform ordinance design. ${ }^{14}$ Wind energy ordinances often include elements focused on land use, sound standards, safety, electrical systems, permitting, height, and setbacks. Comprehensive ordinances can also outline the types of wind development that can occur without a permit and the processes for wind development beyond the scope of the ordinance. To support positive outcomes, ordinances also differentiate between small residential or small commercial wind projects and larger utility-scale wind farms. Effective ordinance design processes typically involve inclusive stakeholder engagement and consultation with leaders and members of the community in relation to the ordinance elements mentioned above. To improve efficiency of wind ordinance processes, policymakers can also consider development of regional model zoning ordinances and educating local planning officials on ordinance processes and responsible siting requirements (Forsyth and Baring-Gould 2007).

\footnotetext{
${ }^{13}$ In 2014, the World Bank provided more than \$1.4 billion in lending for various renewable energy projects through its subsidiary, the International Finance Corporation. Wind energy projects received 25\% of this amount (World Bank 2014).

${ }^{14}$ The U.S. Department of Energy WINDExchange initiative maintains a database of over 300 wind ordinances from across the United States. Further resources are available through the distributed wind energy association; see distributedwind.org/zoning-resource-center/.
} 
- $\quad$ Streamlining permit processesPolicymakers can support wind investment through centralizing review and permitting of wind projects. Streamlined permitting involves limiting the number of agencies engaged with permitting to reduce the burden on developers to contact and receive permits from many different agencies. Further, to support streamlined permitting and approvals, fully informing and integrating local communities into wind development decision-making processes is critical, even when conducted at the regional or national level. Text Box 10 presents approaches taken by Germany and Denmark to streamline permitting processes (EWEA 2012).
Text Box 10. Germany and Denmark: Supporting wind power through streamlined permitting and CREZ

Over the last few decades, Germany and Denmark have made significant progress toward streamlined permitting for wind projects. In 1999, Denmark issued a wind power planning directive with regional planning guidelines that designated appropriate locations for wind energy development for regional and municipal authorities. Local governments planning wind energy development could then use the regional planning guidelines to inform development and permitting processes (Petterson and Söderholm 2011). Based on this and other advances, as of 2013, wind-permitting processes were significantly more expeditious in Denmark than they were in the European Union (taking approximately eight fewer months to receive a wind permit) (Danish Energy Agency 2014).

Germany revised its Building Code in 1996 to designate a special status for wind turbines. The special status allows non-urban wind turbines that do not infringe on the public interest to easily receive a construction permit. As with the CREZ approach noted above, and to support local authorities, the government has identified suitable areas for wind development to support private investment (Brunes and Ohlhorst 2011). 


\section{Summary}

Table 1 summarizes the good practices and considerations for the design and implementation of wind power policies that are presented in this paper.

Table 1. Summary of Good Practices and Considerations

\begin{tabular}{|c|c|}
\hline Policy & Good Practice \\
\hline Renewable electricity standards & $\begin{array}{l}\text { - Establishing long-term RES targets that increase over } \\
\text { time to support sustained wind growth } \\
\text { - } \quad \text { Defining the standard to support wind generation } \\
\text { - Enacting subnational RESs to support diverse wind } \\
\text { resources and development needs } \\
\text { - Establishing set-asides for offshore wind technologies } \\
\text { - Supporting a broader enabling policy environment. }\end{array}$ \\
\hline Feed-in tariffs & $\begin{array}{l}\text { - } \text { Differentiating wind FIT payments in relation to resource } \\
\text { - } \quad \text { Differentiating wind FIT payments in relation to project } \\
\text { size } \\
\text { - Differentiating wind FIT payments for offshore wind } \\
\text { development } \\
\text { - Differentiating wind FIT payments in relation to } \\
\text { technology } \\
\text { - Considering bonus payments and premiums to support } \\
\text { broader wind development goals } \\
\text { - Considering wind FIT price degression. }\end{array}$ \\
\hline $\begin{array}{l}\text { Interconnection standards and net } \\
\text { metering for distributed wind }\end{array}$ & $\begin{array}{l}\text { - Establishing interconnection standards } \\
\text { - Considering a wind net metering policy. }\end{array}$ \\
\hline $\begin{array}{l}\text { Wind investment and production tax } \\
\text { credits }\end{array}$ & $\begin{array}{l}\text { - Establishing an appropriate incentive rate and } \\
\text { - } \text { controlling costs } \\
\text { - } \quad \text { Determining the tax incentive period } \\
\text { - Wind production tax credit considerations } \\
\text { - Wind investment tax credit considerations } \\
\text { - } \quad \text { Supporting non-taxable entities. }\end{array}$ \\
\hline $\begin{array}{l}\text { Further approaches to support private } \\
\text { investment }\end{array}$ & $\begin{array}{l}\text { - Identifying Competitive Renewable Energy Zones } \\
\text { - } \quad \text { Reducing risk and cost of capital } \\
\text { - Designing wind ordinances } \\
\text { - Streamlining permit processes. }\end{array}$ \\
\hline
\end{tabular}




\section{References}

American Wind Energy Association. 2014a. Federal Production Tax Credit for Wind Energy. www.awea.org/Advocacy/Content.aspx?ItemNumber $=797$

American Wind Energy Association. 2014b. Federal Wind Energy Policy. www.awea.org/Advocacy/Content.aspx? ItemNumber $=6900$

Asian Development Bank. 2013. Assessment of the Greater Mekong Subregion Energy Sector Development: Progress, Prospects, and Regional Investment Priorities. Mandaluyong City, Philippines: Asian Development Bank. http://www.adb.org/sites/default/files/institutionaldocument/33872/files/assessment-gms-subregion-energy-sector-development.pdf.

Bipartisan Policy Center. 2011. Reassessing Renewable Energy Subsidies: Issue Brief. Washington, DC: Bipartisan Policy Center. http://bipartisanpolicy.org/wpcontent/uploads/sites/default/files/BPC_RE\%20Issue\%20Brief_3-22.pdf.

Boekhoudt, Andre, and Lars Behrendt. 2014. Taxes and Incentives for Renewable Energy. KPMG International Cooperative. http://www.kpmg.com/global/en/issuesandinsights/articlespublications/taxes-and-incentives-forrenewable-energy/pages/india.aspx

Brunes, Elke, and Dörte Ohlhorst. 2011. "Wind Power Generation in Germany: A Transdisciplinary View on the Innovation Biography." The Journal of Transdisciplinary Environmental Studies 10:1.

Cochran, Jaquelin, Lori Bird, Jenny Heeter, and Douglas J. Arent. 2012. Integrating Variable Renewable Energy in Electric Power Markets: Best Practices from International Experience. Golden, CO: National Renewable Energy Laboratory.

Couture, Toby D., Karlynn Cory, Claire Kreycik, and Emily Williams. 2010. A Policymaker's Guide to Feed-in Tariff Policy Design. Golden, CO: National Renewable Energy Laboratory.

Danish Energy Agency. 2014. Procedures and Permits for Offshore Wind Parks. http://www.ens.dk/en/supply/renewable-energy/wind-power/offshore-wind-power/procedurespermits-offshore-wind-parks

Danish Wind Energy Association. 2015. Wind Energy.http://denmark.dk/en/green-living/windenergy/

DECC (UK Department of Energy and Climate Change). 2008. Microgeneration Installation Standard: MSC 001, Installer Certification Scheme Requirements. London: Department of Energy and Climate Change.

EU (European Union) Good Practice Wind. 2013. GP Wind Good Practice Guide. http://projectgpwind.eu/good.pdf

EWEA (European Wind Energy Association). 2012. European Wind Industry perspective on Good Practices for Grid Access and Permitting procedures. http://www.feed-incooperation.org/wDefault_7/download-files/9th-workshop/presentations/session-6/Tardieu.pdf 
Forsyth, T., and I. Baring-Gould. 2007. Distributed Wind Market Applications. Golden, CO: National Renewable Energy Laboratory.

Gsanger, Stefan. 2013. 2013. 2013 Small Wind World Report Update. Bonn, Germany: WWEA (World Wind Energy Association). http://www.wwindea.org/webimages/SWWR_summary.pdf.

IEA (International Energy Agency). 2014. IEA Wind 2013 Annual Report. Paris: IEA.

IREC (Interstate Renewable Energy Council). 2014. Freeing the Grid 2014. United States: IREC.

IRENA (International Renewable Energy Agency). 2012. 30 Years of Policies for Wind Energy. https://www.irena.org/DocumentDownloads/Publications/IRENA_GWEC_WindReport_Full.pdf.

Iowa Wind Energy Association. 2015. Iowa Wind Energy Fact Sheet.

http://www.iowawindenergy.org/readmore.php?idnews $=113$

ITAMS (International Trade Administration Manufacturing and Services), Office of Energy and Environmental Technologies. 2013. Chile's Renewable Energy and Energy Efficiency Market: Opportunities for U.S. Exporters. International Trade Administration. http://export.gov/build/groups/ public/@eg_main/@reee/documents/webcontent/eg_main_059190.pdf.

Klein, Arne, Erik Merkel, Benjamin Pfluger, Anne Held, Mario Ragwitz, Gustav Resch, and Sebastian Busch. 2010. Evaluation of Different Feed-in-Tariff Design Options. Germany Ministry for the Environment, Nature Conservation and Nuclear Safety (BMU). $3^{\text {rd }}$ edition. http://www.feed-incooperation.org/wDefault_7/download-files/research/Best_practice_Paper_3rd_edition.pdf.

Lantz, Eric, Daniel Steinberg, Michael Mendelsohn, Owen Zinaman, Ted James, Gian Porro, Maureen Hand, Trieu Mai, Jeffrey Logan, Jenny Heeter, and Lori Bird. 2014. Implications of a PTC Extension on U.S. Wind Deployment. Golden, CO: National Renewable Energy Laboratory.

Mendelsohn, Michael, and Claire Kreycik. 2012. Federal and State Structures to Support Financing Utility-Scale Solar Projects and the Business Models Designed to Utilize Them. Golden, CO:

National Renewable Energy Laboratory.

Otis, John. 2015. Nicaragua's Renewable Energy Revolution Picks Up Steam. National Public Radio. http://www.npr.org/sections/parallels/2015/03/11/392111931/nicaraguas-renewable-energyrevolution-picks-up-steam.

Petterson, Maria, and Patrik Söderholm. 2011. Reforming Wind Power Planning and Policy: Experiences from the Nordic Countries. CESifo DICE Report. http://www.cesifogroup.de/ifoHome/publications/docbase/details.html?docId=17567600.

Polaris. "Net Metering.” Accessed May 6, 2015. http://www.polarisamerica.com/wind-basics/netmetering/

Public Utility Commission of Texas. 2014. CREZ Progress Report No. 14: Jan Update. Prepared by RS\&H. http://www.texascrezprojects.com/page29602253.aspx.

RED Electrica de Espana. 2014. The Spanish Electricity System Preliminary Report. http://www.ree.es/sites/default/files/downloadable/preliminary_report_2014.pdf 
REN21 (Renewable Energy Policy Network for the 21st Century). 2014. Renewables 2014 Global Status Report. Paris: REN21 Secretariat.

REN21 (Renewable Energy Policy Network for the 21st Century). Renewable Interactive Map. http://map.ren21.net/.

Rickerson, Wilson, Chad Laurent, David Jacobs, Christina Dietrich, and Christina Hanley. 2012. Feed-in-tariffs as a Policy Instrument for Promoting Renewable Energies and Green Economies in Developing Countries. Paris: United Nations Environment Programme.

Stadelmann, Martin, Gianleo Frisari, and Anja Rosenberg. 2014. The Role of Public Finance in CSP: Lessons Learned. Climate Policy Initiative.

UNDP (United Nations Development Programme). 2012. Transforming On-Grid Renewable Energy Markets: A Review of UNDP-GEF Support for Feed-in Tariffs and Related Price and Market-Access Instruments. New York.

http://web.undp.org/gef/document/UNDP FIT_Port_TransformingREMarkets

15oct2012.pdf

Wiser, Ryan H., and Mark Bolinger. 2014. 2013 Wind Technologies Market Report. Washington: U.S. Department of Energy.

World Bank Group. 2014. World Bank Group Energy Lending Focuses on Poorest Regions: Boost in Renewable Energy Financing. http://www.worldbank.org/en/news/feature/2014/09/05/boost-inworld-bank-renewable-energy-lending..

WWEA (World Wind Energy Association). 2014. Small Wind World Report 2014. Bonn, Germany: WWEA. 


\section{Appendix. Additional Support and Resources}

The following resources can be used to support more detailed design and implementation of policies to support wind power deployment. Targeted technical assistance regarding the design and implementation of renewable energy policies is provided by:

Clean Energy Solutions Center-The Solutions Center's Ask an Expert service is available at no cost to government agency representatives from any country and the technical institutes assisting them. If your request qualifies for assistance, you will be matched with the Solutions Center expert who is most qualified to help you, for up to 40 hours of assistance. To submit a request for assistance, see cleanenergysolutions.org/expert.

Climate Technology Centre and Network (CTCN)—-The CTCN provides technical assistance in response to requests submitted by developing countries via their National Designated Entities. Upon receipt of such requests, the centre quickly mobilizes its global network of climate technology experts to design and deliver a customized solution tailored to local needs. The CTCN does not provide funding directly to countries but instead supports the provision of technical assistance provided by experts on specific climate technology sectors. For more information, see ctc-n.org/technical-assistance.

Additional resources - including good practice resources and publications, policy examples and databases, webinars and training resources, and a glossary_-are available at cleanenergysolutions.org/policy-briefs/wind. 